Вісник Дніпропетровського університету. Біологія. Екологія. - 2008. - Вип. 16, т. 1. - С. 99-103.

Visnyk of Dnipropetrovsk University. Biology. Ecology. - 2008. - Vol. 16, N 1. - P. 99-103.

УДК 577.23

В. І. Карпенко, С. І. Писарєв, Л. П. Голодок

Національний авіаційний університет, м. Київ,

Дніпропетровський національний університет

\title{
ЕНЕРГОЗБЕРІГАЮЧІ СИСТЕМИ 3 ВИКОРИСТАННЯМ МАЛОГАБАРИТНИХ БІОЕНЕРГЕТИЧНИХ УСТАНОВОК
}

Розроблена та пропонується для впровадження комплексна енергозберігаюча система 3 використанням малогабаритних енергетичних установок для присадибних, фермерських маєтків і господарств. Вона являє собою комплекс з енергетично взасмодіючими елементами: будинок - теплиця (зимовий сад) - біогазовий реактор із широким використанням утилізації комунально-побутових i сільськогосподарських відходів.

V. I. Karpenko, S. I. Pysarev, L. P. Golodok

National Aviation University, Kyiv,

Dnipropetrovsk National University

\section{ENERGY-SAVING SYSTEMS WITH THE USE OF COMPACT BIOENERGY DEVICES}

Complex energy-ecology-saving system with the usage of compact power plants has been developed and recommended for country estates, farm houses and lands. The energy-ecology-saving system is a complex consisting of energetically interacting elements: house - hothouse (winter garden) - biogas reactor. Recycling of household and agricultural wastes is used extensively.

\section{Вступ}

Вирішення проблем енергетичної кризи, яку людство починає відчувати вже сьогодні через нестачу традиційних видів палива, ми бачимо через оволодіння та підвищення ефективності використання процесів конверсії сонячної енергії в технічно доступні види палива. Враховуючи високу швидкість біологічних реакцій, їх техніко-економічну рентабельність, одним із перспективних методів може бути конверсія сонячної енергії в біомасу та паливо біоенергетичних систем.

У присадибних, фермерських та інших сільгоспвиробників існують потреби в ефективній утилізації органічних відходів. У той же час сільськогосподарські органічні відходи $є$ природною сировиною для виробництва біогазу як палива та екологічно чистих органо-мінеральних добрив для задоволення потреб цих господарств як у енергоносіях, так і у високоякісних добривах. Для вирішення цієї проблеми в Китаї, Україні, Росії та інших країнах створений ряд біогазових установок [1;2; 7]. Ці установки не отримали широкого впровадження в Україні через малу ефективність енергозбереження та низькі ціни в минулі часи на природний газ. Вихід біогазу у цих установках при концентрації метану до $60 \%$ становив $1-4 \mathrm{~m}^{3} / \mathrm{m}^{3}$ метантенка на добу. При цьому технологічні витрати біогазу на підтримку їх роботи становили 50-100 \% від отриманого біогазу. Такий вихід біогазу одержують і зараз на очисних комунальних спорудах при зброджуванні осаду

(C) В. І. Карпенко, С. І. Писарєв, Л. П. Голодок, 2008 
аеротенків. Концентрація $H_{2} S$ в такому біогазі може становити до $4 \%$, що викликає додаткові проблеми при його використанні. Такі установки не можна назвати енергетичними через відсутність товарного газу як такого. Вихід таких біогазових установок на робочий режим у крайньому випадку може становити 2-3 місяці і більше [4; 5]. Причина малої ефективності цих установок - виникнення різних технологічних і технічних проблем у процесі їх роботи, відсутність комплексного підходу, глибокого наукового обгрунтування вирішення проблем анаеробної переробки органічних відходів тощо. Тому мета нашої роботи - розробити нові енергозберігаючі науково-технічні підходи, які можна впроваджувати на присадибних, фермерських маєтках і господарствах на базі комплексної ресурсозберігаючої системи з використанням малогабаритних енергетичних установок.

\section{Матеріал і методи досліджень}

Використовували сучасні методи виділення та культивування анаеробних метаногенних мікроорганізмів, а також сучасні фізико-хімічні методи досліджень біотехнологічних експериментів [3;6].

\section{Результати та їх обговорення}

За нашою участю на птахофабриці “Київська" раніше була створена пілотна біоенергетична установка з об’ємом метантенка $20 \mathrm{~m}^{3}$. Вихід біогазу при збродженні курячого посліду на цій установці при концентрації метану $85 \%$ становив $7 \mathrm{~m}^{3} / \mathrm{m}^{3}$ метантенка на добу або 140 м³/добу з усього об'єму метантенка. Сірководень практично був відсутній. Технологічні потреби енергоносіїв становили 7 \% від отриманого біогазу. При цьому одержані збалансовані по вуглецю та $N P K$ зброджені відходи, які після стабілізації, хімічного зв'язування летких речовин являють собою високоякісні органо-мінеральні добрива з $N, P$ та $K$. Технологія процесу зброджування та стабілізації органічних відходів дозволяла змінювати співвідношення $N, P$ та $K$ добрив під будь-яку сільськогосподарську культуру. Вихід установки на робочий режим становив 2,5 тижня. Вихід біогазу на кращих європейських біоенергетичних установках (Іспанія) при концентрації метану $80 \%$ становив $4-5 \mathrm{~m}^{3} / \mathrm{m}^{3}$ метантенка на добу.

На замовлення Держкоменергозбереження України розроблена, створена (завод “Красный Октябрь”, м. Фастів), випробувана та рекомендована до впровадження конс-

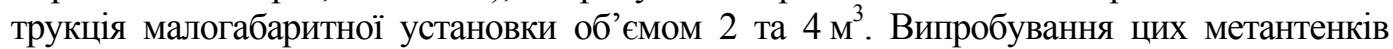
проводилось на комплексі КРС, с. Зазим'я, Київська область, та на птахофабриці “Україна”, м. Васильків, до 2001 року включно. У процесі випробування виявлені й частково ліквідовані як конструктивні, так і технологічні недоробки. Вихід біогазу на цих установках при мезофільному режимі роботи та експозиції відходів у метантенку 10 діб становив 5-6 $\mathrm{m}^{3} / \mathrm{m}^{3}$ метантенка на добу та $10 \mathrm{~m}^{3} / \mathrm{m}^{3}$ метантенка на добу при експозиції відходів 5 діб. При цьому якість збродженних відходів при мезофільному та термофільному режимах роботи метантенка була постійною.

У процесі випробування виявлена залежність виходу біогазу від величини завантаження органічної сировини, експозиції відходів у метантенку, температури та pH зброджених відходів, а також “ноу-хау” відносно умов переходу від одного режиму роботи метантенка до іншого. Крім того, залежно від виду органічної сировини були відібрані найпродуктивніші асоціації анаеробних бактерій. Установлено, що відбір продуктивних асоціацій анаеробних бактерій у кожному конкретному випадку можна реалізувати за допомогою спеціальної конструкції метантенка.

Сьогодні нами розроблена та пропонується для впровадження комплексна енергозберігаюча система 3 використанням малогабаритних біоенергетичних установок 
для присадибних, фермерських маєтків і господарств. Енергозберігаюча система являє собою комплекс з енергетично взаємодіючих елементів: будинок - теплиця (зимовий сад) - біогазовий реактор. Зовнішні стіни будинку та цоколя теплиці виконані тришаровими із керамічної та силікатної цегли 3 шаром штучного чи природного утеплювача. Опір теплопередачі конструкції стіни $-R o \geq 2,2 \mathrm{~m}^{2}{ }^{\circ} \mathrm{C} / \mathrm{B}$. Торцева стіна будинку з боку теплиці на всю висоту запроектована масивною, має виконувати роль теплоакумулятора. Це надасть можливість накопичувати теплову енергію вдень і віддавати іiі до системи вночі, що збільшить інерційність системи опалення та буде сприяти підвищенню комфортності житлових приміщень, стабілізації умов існування рослин у теплиці. Із метою збереження теплової енергії в теплиці передбачено улаштування утеплювального рулонного покриття, що за допомогою механізму відкриває засклену поверхню теплиці вдень і закриває іiі на ніч. При цьому втрата енергії від нічного охолодження зменшується в 1,6 раза.

На основі кількісного аналізу теплового балансу системи показана ефективність блокування теплиці з будинком, а також доцільність улаштування біогазового реактора в теплиці, який забезпечить вироблення біогазу у вигляді газового пального, вдень може акамулювати сонячну енергію для підтримки технологічної температури біореактора $+32^{\circ} \mathrm{C}$ чи $+50^{\circ} \mathrm{C}$. Оскільки температура біогазового реактора вища від температури повітря у теплиці вночі, біореактор буде віддавати частину низькопотенційої енергії у вигляді тепла до навколишнього простору теплиці, створюючи комфортніші температурні умови вирощування сільськогосподарських культур. Це особливо актуально в наших кліматичних широтах, де поширені нетривалі заморозки навесні та восени. Крім цього біогазовий реактор здатний забезпечити виготовлення високоякісних біодобрив на енергозберігаючій основі. Об'єм біогазового реактора доцільно мати до $1 \mathrm{~m}^{3}$ у випадку його використання на малих присадибних маєтках.

У результаті комплексу заходів (завдяки притоку сонячної енергії до теплиці, нагрівання води в колекторах, спалювання отриманого у біореакторі біогазу) щодо підвищення опору теплопередачі огороджувальних конструкцій частка енергії від нетрадиційних джерел у загальному тепловому балансі системи “будинок - теплиця біогазовий реактор" на малих присадибних маєтках може становити понад 26 \%, а опалювальний період у системі зменшується мінімум на 13 діб, завдяки чому економія палива складатиме по будинку - 54 \%, по теплиці - 65 \% (рис.).

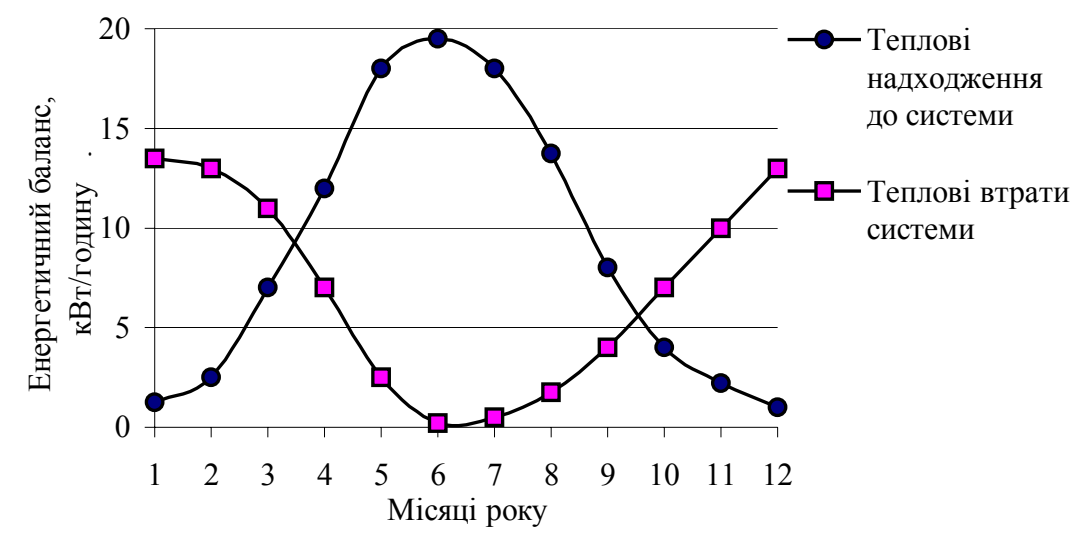

Рис. Теплоенергетичний баланс малогабаритної біоенергетичної установки “будинок - теплиця (зимовий сад) - біогазовий реактор”. 
У присадибних господарствах на біоенергетичній установці при переробці 100150 кг органічних відходів вихід біогазу буде становити 6-8 м ${ }^{3}$ на добу. Цього біогазу недостатньо для задоволення потреб присадибного господарства, які взимку становлять до $50 \mathrm{~m}^{3}$ газу на добу, що еквівалентно 0,5 мВт теплової енергії. Тому на невеликих присадибних маєтках і господарствах присадибні біоенергетичні установки варто додатково оснащувати розробленими нами дешевими теплогенераторами потужністю 0,5 мВт теплової енергії, що дозволить підняти економію палива в системі ще на 10 \%.

Оскільки фермерські господарства в Україні мають від 0,4 до 5,0 т органічних відходів на добу (вологістю 86 \%), біоенергетичні установки для фермерських господарств повинні мати об'єм метантенків 4-50 $\mathrm{m}^{3}$. Треба зауважити, що метантенк являє собою реактор нульового порядку. Тому керовані процеси анаеробної переробки органічних відходів добре масштабуються. При цьому вихід біогазу буде пропорційний об'єму метантенка. Якщо в метантенку об'ємом 1 м $^{3}$ при даній технології переробки органічних відходів отримано $6 \mathrm{~m}^{3}$ на добу, то в метантенку об'ємом $50 \mathrm{~m}^{3}$ при тих самих умовах вихід біогазу становитиме $300 \mathrm{~m}^{3}$ на добу. Вихід добрив також буде пропорційний об’єму метантенка. При виході біогазу $50 \mathrm{~m}^{3}$ і більше потреби фермерського господарства в енергоносіях будуть повністю забезпечені.

У той же час в енергогенерувальній частині цього комплексу на енергозберігаючій основі можна виготовляти високоякісні біоорганічні добрива для теплиці та господарських потреб у цілому. Це дає можливість одержати стабільні, збалансовані, екологічно чисті органо-мінеральні добрива для своєї земельної ділянки. При анаеробній переробці органічних відходів на органо-мінеральні добрива будуть знешкодженні хвороботвірні бактерії, гельмінти та насіння бур'янів, що поліпшить екологічний стан господарства, зменшить зусилля по боротьбі з бур'янами на земельній ділянці. Такі добрива можна вносити протягом усього вегетативного періоду рослин (кореневе підживлення). Після одного-двох років внесення таких добрив урожайність підвищується удвічі-втричі проти традиційного внесення органіки (гною). При цьому поліпшується якість і екологічна чистота сільгосппродукції. Такі добрива (у рідкому стані) вміщують стимулятори росту рослин, придатні для обробки посівного матеріалу, мають захисні властивості проти деяких рослинних захворювань. На присадибній біоенергетичній установці при переробці 100-150 кг на добу органічних відходів можна одержати 110-170 кг рідкого добрива, що цілком достатньо для підтримки родючості земельної ділянки фермерського господарства.

Потенційні замовники малих біоенергетичних установок - присадибні та фермерські господарства. Присадибні маєтки можуть включати дачні садиби та присадибні господарства. Дачні садиби варто розглядати тільки з точки зору енергозбереження експлуатації дачного будинку та отримання біоорганічних добрив на енергозберігаючій основі. Присадибні господарства мають до шести чоловік працівників, до трьох голів великої рогатої худоби, до п'яти свиней, до 50 голів птиці, 30-60 соток землі при садибі і таку ж кількість землі у полі. Кількість органічних відходів таких господарств, разом із зеленою масою чи підстилкою узимку, становить 100-150 кг на добу. Ці відходи мають високий відсоток органічних речовин. Фермерські господарства в Україні дають від 0,4 до 5 т органічних відходів на добу вологістю близько 86 \%.

\section{Висновки}

Наша науково-технічна пропозиція має значно розширити можливості використання малих біоенергетичних установок на присадибних і фермерських господарствах, суттєво підвищити ефективність енергозбереження цих систем. Такий підхід до вирішення проблеми енергозбереження, на наш погляд, не має альтернативи. Тому сьогодні 
авторами проекту ведуться наукові роботи з означених питань, здійснюється підготовка дипломованих фахівців у галузі біотехнології та екології, ведуться роботи зі створення демонстраційної комплексної енергозберігаючої системи з використанням малогабаритних біоенергетичних установок у селищі Глеваха Київської області.

Автори мають інтелектуальну власність, у тому числі “ноу-хау” у галузі переробки органічних відходів, трансформації одних видів енергії в інші, мають тісні зв'язки 3 проектними установами та заводами України та можуть взяти на себе відповідальність за розробку, виготовлення та впровадження комплексних енергозберігаючих систем із використанням малогабаритних біоенергетичних установок на присадибних і фермерських господарствах України на достатньо високому науковому та технічному рівні. Останнє також стосується розробки, виготовлення та запуску великомасштабних біоенергетичних комплексів із об’ємом метантенків 250-1000 м й вище, хоча технологія переробки органічних відходів на великомасштабних біоенергетичних комплексах $\mathrm{i}$ шляхи іiі реалізації значно відрізняються від технології, реалізованої малими біоенергетичними установками.

\section{Бібліографічні посилання}

1. Баадер В. Биогаз / В. Баадер, Е. Доне, Е. Брендерфер. - М.: Колос, 1982. - 130 с.

2. Бекер М. Е. Биотехнология кормопроизводства и переработки отходов. - Рига: Знатне, 1987. $-212 \mathrm{c}$.

3. Взаємодія мікробних популяцій в метаногенних асоціаціях і шляхи збільшення виходу метану в метантенках / В. І. Карпенко, Л. С. Ястремська, Л. П. Голодок та ін. // Вісник Дніпропетр. ун-ту. Біологія. Екологія. - 2006. - Т. 2. - С. 79-83.

4. Гюнтер Л. И. Метантенки / Л. И. Гюнтер, Л. П. Гольдфарб. - М.: Стройиздат, 1991. - 129 с.

5. Карпенко В. И. Синтез белка микроорганизмов на биогазе / В. И. Карпенко, Т. П. Крыштаб, Ф. В. Мучник / Биогаз - 87. Тез. докл. совещ. по технической биоэнергетике. - Рига, 1987. - C. 55.

6. Карпенко В. І. Закономірності трансформації полімерних сполук у метан термофільними анаеробними бактеріями / В. І. Карпенко, Л. С. Ястремська, Л. П. Голодок та ін. // Вісник Дніпропетр. ун-ту. Біологія. Екологія. - 2006. - Т. 1. - С. 79-84.

7. Пузанков А. Г. Обеззараживание стоков животноводческих комплексов / А. Г. Пузанков, Г. А. Мхитарян, Н. Д. Гришаев. - М.: Агропромиздат, 1986. - 175 с.

Надійшла до редколегії 15.01.2007 